\title{
TOURIST AND RECREATIONAL POTENTIAL OF LANDSCAPES OF THE SPECIALLY PROTECTED NATURAL AREA OF SHARYN OF THE REPUBLIC OF KAZAKHSTAN
}

\author{
Bayan S. KERIMBAY* \\ L.N. Gumilyov Eurasian National University (ENU), Faculty of Natural Sciences, \\ Department of Physical and Economical Geography (DPhaEG), st.Kazhymukan, \\ 13, 010000, Nur-Sultan, Republic of Kazakhstan, e-mail: bayan.kerimbay.65@mail.ru
}

Kulchikhan M. JANALEYEVA

L.N. Gumilyov Eurasian National University (ENU), Faculty of Natural Sciences, Department of Physical and Economical Geography (DPhaEG), st.Kazhymukan, 13, 010000, Nur-Sultan, Republic of Kazakhstan, e-mail: dzhanaleeva44@mail.ru

\section{Nurzhan N. KERIMBAY}

L.N. Gumilyov Eurasian National University (ENU), Faculty of Physics and Technical Sciences, Department of Space Engineering And Technology (DSEaT), st.Satpaev, 2, 10000, Nur-Sultan, Republic of Kazakhstan, e-mail: n.kerimbay@mail.ru

\begin{abstract}
Citation: Kerimbay, B.S., Janaleyeva, K.M. \& Kerimbay, N.N. (2020). TOURIST AND RECREATIONAL POTENTIAL OF LANDSCAPES OF THE SPECIALLY PROTECTED NATURAL AREA OF SHARYN OF THE REPUBLIC OF KAZAKHSTAN. GeoJournal of Tourism and Geosites, 28(1), 67-79. https://doi.org/10.30892/gtg.28105-452
\end{abstract}

\begin{abstract}
In this work, we studied the tourist and recreational resources - relict, unique landscapes of the specially protected natural area of the Sharyn. The work is the result of many years of field research on landscapes and summer field practice in 2019 in the Sharyn River basin, the study and systematization of published scientific materials. 4 key sections were laid along 2 routes. On this basis, foci of landscape diversity were identified: relic tracts of Sarytugai with Sogdian ash (Fraxinus sogdiana Bunge), tracts Kurtogay, Moyyntugay and Temirlik with relict morphological sculptures. A digital thematic map was created on ArtGIS 10.1. The "passport" of the existing tourist routes and the "passport" of the recreational load of the protected areas Sharyn have been completed. To remove the anthropogenic load on the Sharyn Canyon, it was proposed to develop two more routes: "Small Canyon" and "Temirlik tract." The scientific base of the tourist and recreational potential has been created and the feasibility of further development of international tourism has been substantiated.
\end{abstract}

Key words: Sharyn Canyons, Castle valley, landscape, natural boundary, refugium, morphosculptures, Sogdian ash, tourist routes 


\section{INTRODUCTION}

Tourism is considered to be one of the most active and important industry in many countries and plays a vital role by contributing to economy of many developing countries (Akbar et al., 2020, p. 35). Tourism plays a significant role in the global tourism and hospitality industry, and according to forecasts of experts, including the World Tourism Organization, its growth rates will continue to be high, and the income generated will make a significant contribution to the development of economies of various countries of the world (Aliyeva et al., 2019, p. 3). The aim of this work is: to study at the present stage of the tourist and recreational potential of landscape refugium of SPNA (specially protected natural areas) of Sharyn. Landscape refugium are a relief or other natural objects in which, due to the unique combination of landscape-forming factors and low economic development, characteristic and rare relict geosystems for the region have been preserved. The idea of refugiums has long been established in Western and Russian biological science and literally means "shelters" - areas of the earth's surface where one species, or more often a whole group of living forms, survived an unfavorable period of geological time during which these forms disappeared in other spaces. Studied Landscape refugium (Chibilev, 1999).

To achieve this goal, the objectives are: landscape field research in key areas; creation of a geographic information database. The relevance of the study is the need for integrated landscape research. Landscape is a concept and structure that can be used as an approach to enhance the implementation of tourism policy. The study of recreational conditions and resources of the living environment of the population is a special area of comprehensive landscape and geographical study of the territory (Mazhitova et al., 2018, p. 19). The object of research in administrative relations is located within the Uyghur and Kegen districts of the Almaty region, Republic of Kazakhstan. A feature of the studied object is that it is located along the mountain river Sharyn. Below the confluence of the large left tributary of Karkara, the river enters a narrow valley - Aktogay tract. Further the river, having passed the relic tracts Kurtogay, Moyyntokay and Sarytogay, goes to the Ili Valley. One of the main tributaries is the right bank of the Temirlik River.

\section{RESEARCH METHODS AND MATERIALS}

The methodological basis and theoretical concepts of the systems approach in landscape science were developed in the works of many scientists (Krauklis, 1979; Solntsev, 1981; Retyum, 2017; Snytko \& Semenov, 2008; Tandaric, 2015).

The landscape approach as newly adopted in the development context is rooted in integrative landscape research with a long tradition in geography and planning. landscape research puts the analyses of pattern and processes within the landscape at center stage, on the other side, landscape research focusses on holistic approaches, in which landscape is understood as "an area, as perceived by people, whose character is the result of the action and interaction of natural and/or human factors" (Burgi et al., 2017, p. 1372).

In the doctrine of the geosystem-basin approach (Janaleyeva, 1993; Janaleyeva, 2010) defined the concepts of structural organization, a number of works on this topic were carried out, where a geosystem-basin approach was substantiated when studying the natural environment of the Republic, including the Sharyn subgeosystem under Balkhash- Ili mega-geosystem. The methodological basis for physical geography is presented in the writings of scientists (Gorbunov \& Gorbunova, 2013; Kerimbay, 1998; Kerimbay, 2015; Veselova \& Shmarova, 2016; Zhandaev, 1972), the provisions of the concept of protected areas (specially protected natural areas) are described in the works of (Chibilev, 2011); Characteristics of individual species of relic plants - living witnesses of the flora of previous eras, preserved to our time, including Sogdian ash, growing in the 
Sharyn river basin, studied (Wintergoller, 1984). Sogdian Ash (Fraxinus sogdiana Bunge), was first discovered by P.P. Semenov-Tyan-Shansky in 1857 on the banks of the Ili River (in the Sharyn River Delta). We believe that the most effective way to preserve the natural and biological diversity of landscape refugium is to comprehensively study them. The methods and approaches of landscape-recreational research have been studied in publications (Dunets, 2011; Kabiyev et al., 2018; Mazhitova et al., 2018; Nazarova et al., 2019; Wendt, 2018). The method of "key" sites is used to study the most typical and important geosystems, the study of which will solve the main problems necessary for landscape mapping (Makunina, 1987; Beruchashvili \& Zhuchkova, 1977).

When conducting field research, the employees of the Department of Science of the Sharyn SNNP (State National Natural Park) took active part. A lot of information was obtained from the archive of this department (Chronicle of Nature, 2018a, 2018b).

Protected areas play a major role in landscape diversity, high conservation value, namely those that are unique or relict landscapes, characteristic natural or anthropogenic - natural types of geosystems; ensure the maintenance of a population of background, characteristic, rare and economically significant species. Rare plant species, rare relief types, etc. can be model groups for creation. In the structure of protected areas, the core "nodal territories" of world and national significance, landscape refugium "foci of landscape diversity" stand out. On the territory of protected areas Sharyn 2004 according to the Decree of the Government of the Republic of Kazakhstan No. 213, the Sharyn SNNP (State National Natural Park) was organized on an area of 127,050 hectares in order to preserve and restore the unique natural complexes of the Almaty region. The territory has a special environmental, historical, scientific, aesthetic and recreational value. The main task of the Sharyn SNNP is to protect and expand the habitat of rare and endemic species of animals and plants, as well as their communities, listed in the Red Book of the Republic of Kazakhstan; protection of unique geological objects with morphosculptures. The Sharyn Canyon is included in the list of geological and geomorphological objects and in the list of subsoil areas of particular value. Here, the steep rocky slopes of the canyon, paleontological finds, including fossil animals found in the area, as well as rare species of fauna and flora are protected (Betemesov \& Toktasynov, 2013; Ogar et al., 1997; Kolisnichenko et al., 2013). In 2018, by the decision of the 30th session of the International Coordinating Council of the UNESCO Program "Man and the Biosphere", the Sharyn Biosphere Reserve was included in the UNESCO international network of biosphere reserves. The Sharyn Biosphere Reserve with an area of 239.7 hectares is located in the Sharyn River Basin. It is a unique biogeosystem in the central part of the Ili intermountain basin. The reserve combines the canyon-like valleys into a single whole.

General characteristic of the landscape topography and climate. The mountainous surroundings of the territory are represented by the midlands with absolute heights of $1800-2000 \mathrm{~m}$. The steeply sloping manes and ridges are separated from each other by valleys of temporary watercourses with a depth of 300-500 m. Low mountains are developed at absolute heights of 1400-1800 m, represented by a combination of ridges, separated by gorge-like valleys of watercourses, logs with a depth of $150-200 \mathrm{~m}$. On the slopes, gravel screes are developed. The alluvial-proluvial plain, stretching along the mountains to the Sharyn River, has an almost flat surface, intersected by river valleys with different depths of incision. In the Sharyn river valley, floodplain and floodplain terraces with a decrease in the absolute elevations along the channel from 755 to $605 \mathrm{~m}$ above sea level, with a fall from the southwest to the northeast, are clearly pronounced over wide sections. In places of sharp turns of the channel and narrowing of the valley, clamps and cone of deluvial deposits prevail. A section of a valley composed of 
sedimentary metamorphic rocks forms a deeply eroded canyon with steep slopes in the form of colored weathered rocks resembling castle walls and fairy-tale characters.

The variety of tourist values of the places increases the possibilities of practicing various types of tourism (Kabiyev et al., 2018, p.645). The climate on the territory of protected areas Sharyn is desert continental. The average annual temperature is about $+5^{\circ}$ $\mathrm{C}$, the coldest month (January) $-6^{\circ} \mathrm{C}$, the warmest (July) - about $+27^{\circ} \mathrm{C}$. The frost-free period in the air lasts 180 days, and atmospheric drought lasts about 40 days. The snow cover is shallow (10-20 cm), lasts about 60 days: it is established on average on December 20, and is destroyed on February 20. The total precipitation is about $150 \mathrm{~mm}$ per year (Kerimbay, 2015, p.39). The water temperature in the Sarytogay tract in April is $8.2^{\circ} \mathrm{C}$, in July $-17.5^{\circ} \mathrm{C}$, and the transition through $0.2^{\circ} \mathrm{C}$ is observed on December 5 . In late December, the river banks are covered with ice, which disappears in late February - early March. Field studies were conducted on predefined routes and key areas. In total, during the field research period in the summer of 2019, 2 routes Kurtugay - Mointugay - Temirlik were laid; Moyintugai - Sarytogay. As a result of these studies, key sections (Table 1) of the Kurtugay, Mointugay, Temirlik tracts with relict morphosculptures and the Sarytogay tract with relict vegetation species were identified and studied in detail (Figure 1).

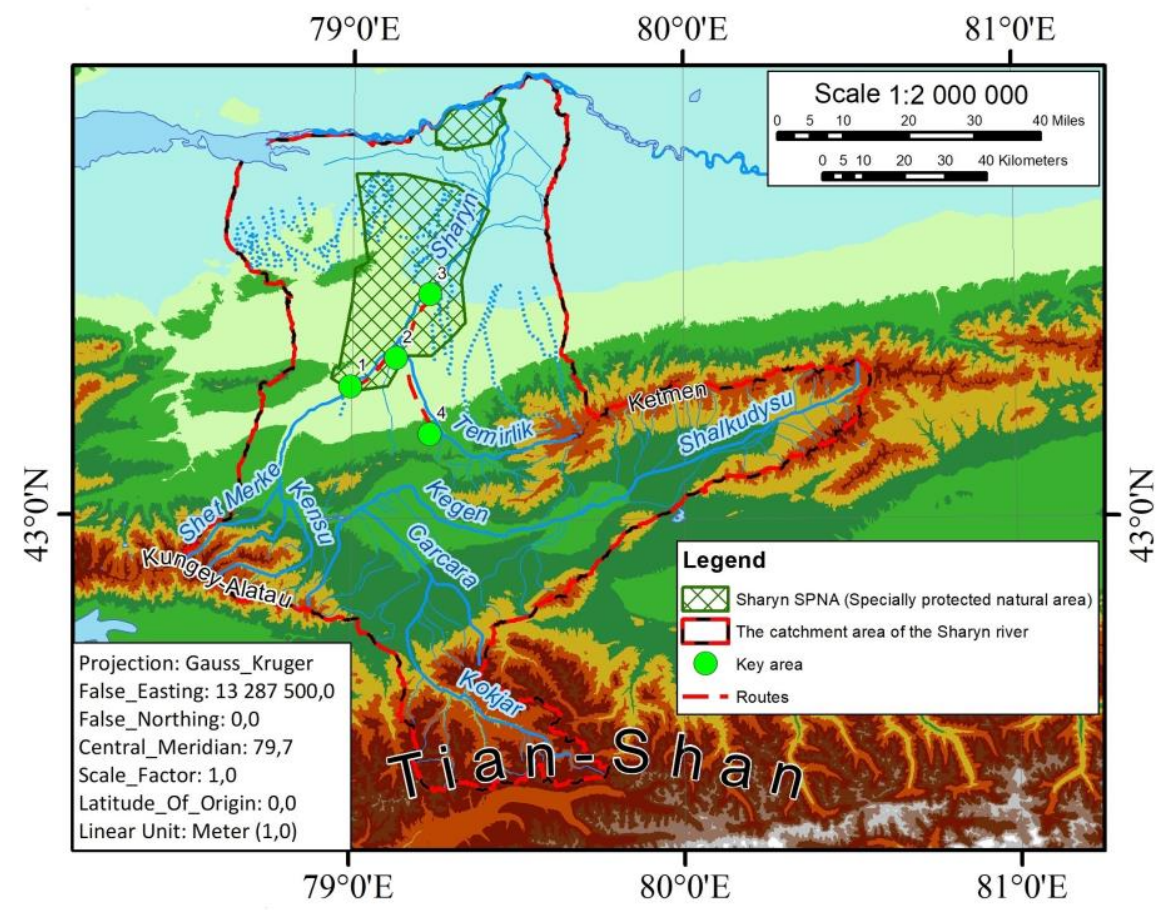

Figure 1. Diagrammic Map of Key Areas of Summer Field Research in 2019

Name and location key areas:

1. Kurtogay tract, near the Sharyn River, $500 \mathrm{~m}$ from the bridge on the A-6 highway;

2. End of Sharyn Canyon, Moyynthay Valley with Canyons;

3. Ash tree Sogdian grove, $50 \mathrm{~km}$. from dirt road, Sarytogay tract;

4. Temirlik Canyons, $3.5 \mathrm{~km}$. from highway A-7, the western outskirts of the village of Temirlik. 
The tracts are located in the basin of the middle and lower reaches of the Sharyn River. The beginning of the tract is $4 \mathrm{~km}$ above the mouth of the Temirlik river and ends at $5 \mathrm{~km}$. in front of the bridge on the Almaty-Zharkent highway, not only landscapes as a whole are unique here, their individual components are unique, especially the relief is the basis for the formation and differentiation of landscapes.

In all key areas, work began with navigation: receiving satellite signals, determining coordinates, determining absolute altitude. The relief description was carried out according to external morphological data, the meteorological data to of the air were determined, fluctuating between +270 and +290 , the direction and speed of the S-b wind, $4-5 \mathrm{~m} / \mathrm{s}$. To study the vegetation, geobotanical sites $1 \times 1 \mathrm{~m}$ in size were laid.

\section{Key area № 1}

N.l. $43^{\circ} 17.185$ / east.l. $78^{\circ} 97.392$ /

height above sea level $1252 \mathrm{~m}$.

Date: 06/18/2019

At the Sharyn River, 500 meters from the bridge on the A-6 highway, natural boundary Kurtugay (Figure 2). The site is confined to the middle reaches of the Sharyn river, composed of boulder-pebble-sand deposits with solyanka-ephemeral-wormwood vegetation on gray-brown soils. Kurtogay hilly-inclined plain with deep sai (Figure 3).

The natural boundary Kurtogay is located in the immediate vicinity of the bridge over the Sharyn River, 200 kilometers east of Almaty. Here are observed the terrigenouscarbonate stratum of the Miocene, overlapping the light gray very strong weathering crust along coal-bearing volcanics. The entire Neogene sequence is colored in reddish and yellowish tones. Carbonic volcanic rocks themselves are represented in the form of beautiful outcrops of tuffs with large rounded fragments of volcanic rocks, then they are replaced by the thickness of a tuff lava, the rock outcrops of which, reminiscent of stone idols, form the walls of the narrowest section of the canyon. This rock consists of particles of molten lava, raised into the air as a result catastrophic explosions. Quite large fragments of lava stand out among tuff lavas to $50 \mathrm{~cm}$. Then the canyon expands, and a volcanic sedimentary thin layer with a lenticular horizon of gray tuffs about $2 \mathrm{~m}$ thick is exposed on its right side. Impressive outcrops of intrusive and volcanogenic rocks are observed in the gorge, at the base of which (near the mouth of the canyon) are granites.

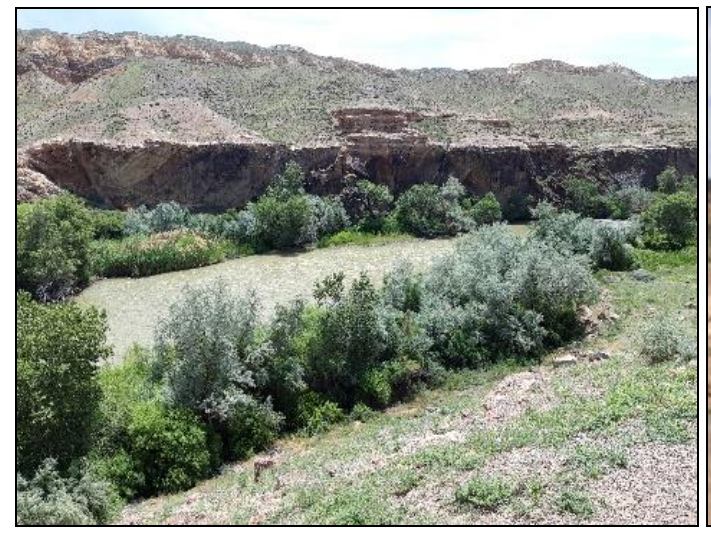

Figure 2. Kurtogay natural boundary

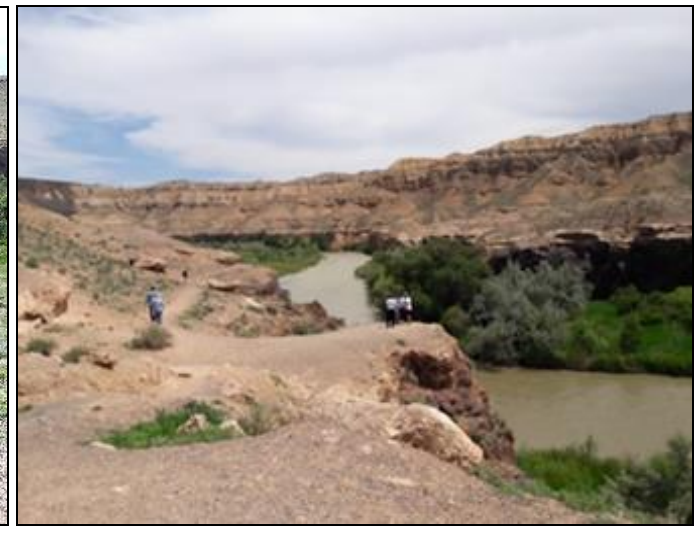

Figure 3. Kurtogay hilly-inclined plain with deep ravine

From the east, to the right side of the tract Kurtogay adjoins a site with an extremely dissected relief. Numerous gullies and ravines, wriggling, intersecting and newly 
disconnecting, form a dense, disordered network, the so-called poorland. The term literally translated from English means "barren land" - include many landforms - small hills, plains, sand massifs, canyon slopes to the canyon with many terraces, caves, grottoes , bizarre single rocks, etc. On the laid geobotanical site (1x1) a description of the vegetation is made. The characteristic vegetation is herb-shrub-poplar (Populus diversifolia, P. nigra, Salix kirillovii, Rosa iliense, Trachomitum lancifolium, Clematis orientalis) along the channel, and shrub thickets (Rosa plathyacantha, R. silverhjelmii, Berberis cleis iliensiens iliensiens iliensiens) terraces in combination with single shrubs (Atraphaxis virgata, Caragana kirghisorum, Ephedra intermedia, Salsola arbuscula) rocky steep slopes.

Project coverage - $65 \%$ - is quite plentiful.

Vitality: medium not full bloom;

does not grow in widespread clusters.

Key area № 2

N.l. $43^{\circ} 24.231$ / east.l. $79^{\circ} 10.218$ /

height above sea level $1121 \mathrm{~m}$.

Date: 06/19/2019

Moyyntokay valley with canyons, the end of the Sharyn canyon.

It is represented by a valley with canyons, with narrow gorges, cut in porphyrites and bedrock rocks with sparse xerophytic-cereal-shrub vegetation on alluvial meadow soils.The natural boundary Moyyntokay extends from the exit of Sharyn from the gorge cut into the spur of Toraigyr to the mouth of Temirlik. This is a narrow canyon 200-300 $m$ wide (Figure 4). The river Sharyn in the Kegen valley after the confluence of Karkara and Kegen, as a result of erosion-accumulative processes, formed a valley - a canyon with morphosculptures, this is a grandiose ravine (sai) "Castle Valley".

In the Sharyn Canyon, the height of the rocks reaches three hundred meters, and the total length of the canyon is more than $15 \mathrm{~km}$. along the sides of the canyon ravine, weathering processes, temporary water currents, strong winds carved bizarre cliffs resembling the ruins of ancient castles. According to the work of geologists (Aubekerov et al., 2003) here, a mineralogical change in the granites of the Ordovician period is observed from the initial pink-brown to bluish-green color with the introduction of magma in the Carboniferous period. In the Holocene of the Quaternary, as a result of erosion-accumulative processes, solar energy, from plastic sedimentary rocks, mainly from sandstone, which gives the walls of the gorge reddish hues, the gorge acquired its current appearance, hanging over the river of morphosculptures in the form of palaces, towers and minarets (Figure 5). The tract cuts through the Toraigyr ridge. Here, magmatic contact of Ordovician granite (orange with blue inclusions) and carbon rhyolitic lava (blue-turquoise color) is observed (Gorbunov \& Gorbunova, 2013).

An array of carbonic volcanic rocks of the Toraigyr mountains is currently advancing on the Neogene plains, the process of thrusting carbonic volcanic rocks on the Pliocene breccias is ongoing at the northern foot of the Toraigyr ridge, at the southern foot of the Yellow Canyon in Pliocene clays and boulder-pebbles. Neogene pattums (pattum-mixed, unsorted) sand-aleuritic-clay rocks of the Castles Valley contain a lot of rubble - the product of rock destruction of the northern macro slope of Toraigyr. The whitish lenses of lake sediments, mainly marls (clay-calcareous rocks), are also noteworthy. In the Valley of Castles, Neogene deposits overlap a rocky shallow hive composed of effusive rocks (volcanic rocks) of the Upper Paleozoic (Carboniferous). These dark rocks are clearly visible on the starboard side of the saya, especially at the place of its exit to Sharyn, where the canyon reaches a depth of $200 \mathrm{~m}$. Here, a mineralogical change in the granites of the Ordovician period is observed from the initial pink-brown to bluish-green color with the introduction of magma in the Carboniferous 
period. In the Holocene of the Quaternary, as a result of erosion-accumulative processes, solar energy, from plastic sedimentary rocks, mainly from sandstone, which gives the walls of the gorge reddish hues, the gorge acquired its current appearance, hanging over the river of morphosculptures in the form of palaces, towers and minarets.

On the laid geobotanical site $(1 \mathrm{~m} \mathrm{x} 1 \mathrm{~m})$ a description of the vegetation is made.

Astragalus Sharynsky, Iliysky cutter, Kashgar rabbit, Sisoluy turanga, Kolpakovsky tulip (Astragalus Sharynsky, Kashgar leporelabrum, Populus Salicaceae, Tulipa Kolpakovsky) and other communities (Chronicle of nature, §2, 2018).

Project coverage - $55 \%$ - quite plentiful

Vitality: medium not full bloom; does not grow in widespread clusters.

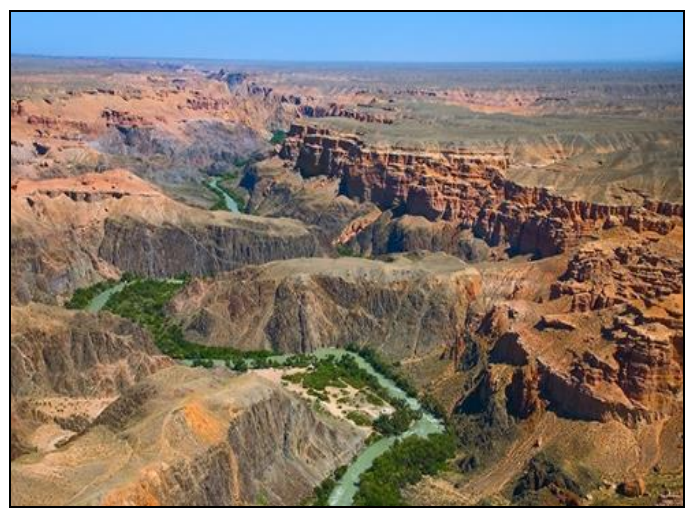

Figure 4. Moyyntokay Valley with canyons

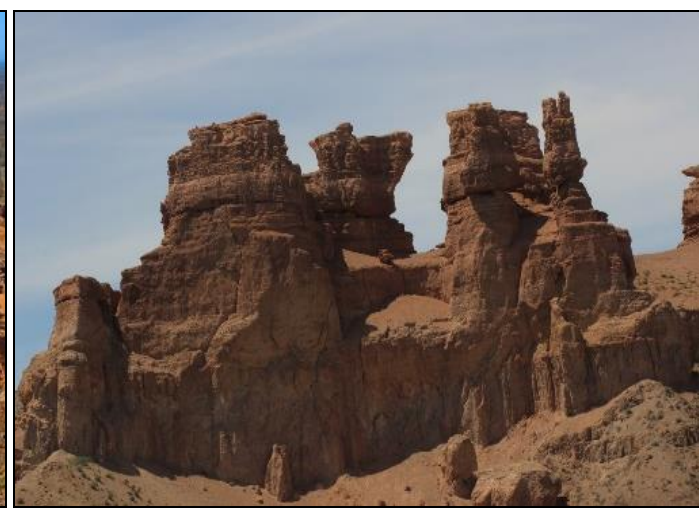

Figure 5. Morphosculptures in the canyon

Key area № 3

N.L. $43^{\circ} 30.972$ / E.l. $079^{\circ} 15.046$ /

height above sea level $787 \mathrm{~m}$.

Date: 06/24/2009

Grove ash Sogdian (Figura 6), 50 meters from the highway, on the northern outskirts of the village of Bahar, Uyghur district, natural boundary Sarytogay (Figure 7).

The northern edge of tugai ash with grassy meadows on alluvial tugai soils. It is represented by the Sarytogay Valley with numerous sai and small mounds composed of pebble-sandy loamy deposits. The soil profile includes a gray-humus horizon of gray color, lumpy, with a poorly diagnosed layer; deluvium rolled stones; the thickness of the horizon is $20-30 \mathrm{~cm}$. The Sarytogay (Ash Grove) tracts (about $25 \mathrm{~km}$ long) are the widest (in places up to $2 \mathrm{~km}$ ) in the Sharyn valley with a depth of not more than $100 \mathrm{~m}$.

Due to the rare combination of a number of geological factors, the interesting locations of the most ancient representatives of the flora have been preserved in the Ash Grove. Sogdian ash (Figura 8) - a relic grove of the Paleogene period, survived the era of glaciation. Sogdian ash tree (Chronicle of Nature, §2, 2018) up to 20-25 meters high, with a trunk diameter of up to 1.5 meters at chest height. The bark is light gray, fissured. Branches are reddish or gray, young pubescent. The crown is openwork, rounded, in old specimens it is very spreading and reaches enormous size. In the Ashen Grove, 400-yearold ash with 4.5 girths, 300-year-old ash in 3.5 girths and 300-year-old ash in 3 girths are common. The bark of the trees is light gray, the branches are reddish-brown, and the leaves are very long - up to $20 \mathrm{~cm}$. The wood-loving ash tree has very valuable wood. The area of the ash forest in Sarytugaev in 1926 was about 1100 hectares, in 1943 - only 410 hectares. This time, the area of the ash forest increased to 812 hectares. In addition 
to ash, various shrubs and trees grow in Sarytogay. On the saline high floodplain terraces, two types of turanga (variegated and sisolate), very original in floristic composition, are common - also the same age as Sogdian ash, and is a relic and endemic (Figura 9). In the undergrowth are common willows, rose hips - Ili and Alberta, as well as rare red-book species - Barberry Ili and Honeysuckle Ili. In rarefied ash forests, a layer of coarse grass is well developed (kendyr lanceolate, Ural licorice, medicinal asparagus, multifooted scythe, etc.). In the clearings and clearings, dense thickets of shrubs (barberry, dogrose, chingil, comb) are common. In Kazakhstan, this type of ash is also called Turkestan, Syrdarya, riverine, and reloving because of its confined plantation in mountain river valleys, it is the only one not only in Kazakhstan, but also in Central Asia.

On the laid geobotanical site (1x1) a description of vegetation is given.

Characteristic number of communities (Chronicle of Nature, §2, 2018): ash (Fraxinus sogdiana) with a rare lower tier from Asparagus officinallis and Ribes saxatile $\rightarrow$ sea buckthorn-willow-sucker (Elaeagnus ochusarra, Salix angustifolia, Hippophae rhamnoides, $\rightarrow$ poplar-ragenogen P. alba) from (Rosa iliensis, Lonicera iliensis, Berberis iliensis) $\rightarrow$ sucker-shrub (Elaeagnus ochusagra, Salix alba, S. kirillovii, Hippophae rhamnoides, Clematis orientalis) on alluvial low-lying boggy soils and.

Project coverage - $95 \%$ - a lot

Viability: full viability, (plants have normal growth) full bloom; grows in common clusters.

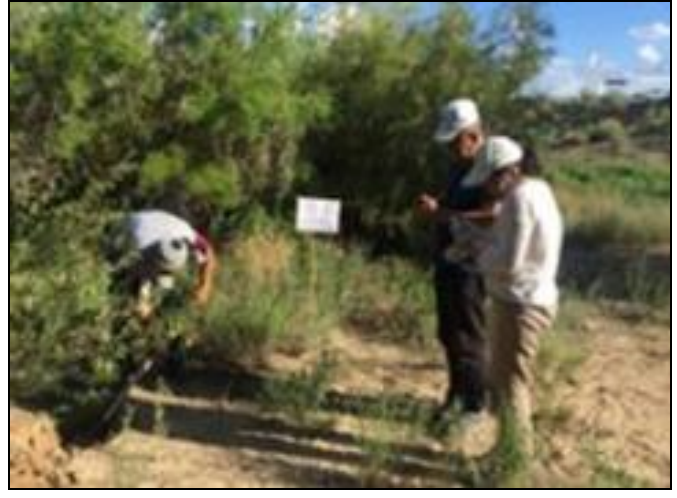

Figure 6. Study of Grove ash Sogdian

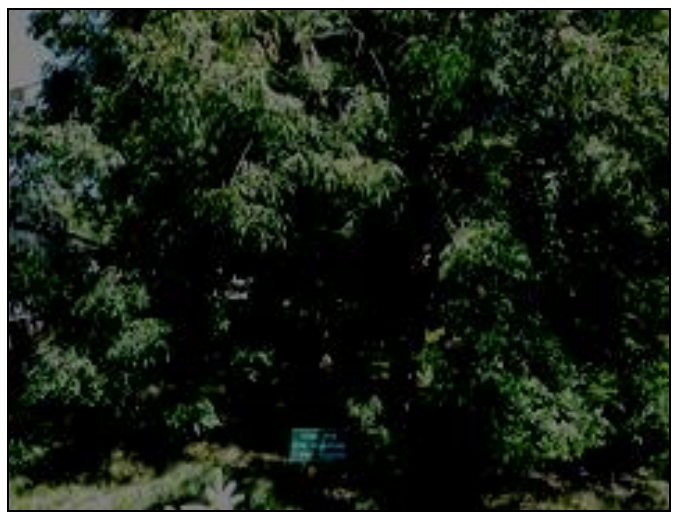

Figura 8. Sogdian ash (Fraxinus Sogdiana)



Figure 7. Natural boundary Sarytogay

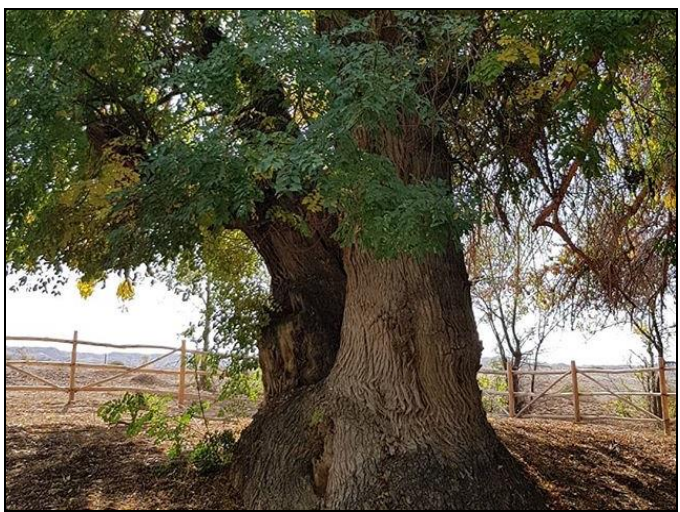

Figura 9. Turanga poplar, age 400 years 
Key area № 4

N.l. $43^{\circ} 05.918$ / east.l. $79^{\circ} 25.762$ /

height above sea level 1099m.

Date: 06/20/2019

$3.5 \mathrm{~km}$. from highway A-7 Shonzhi-Kegen, the western outskirts of the valley of Temirlik, Kegen district, Temirlik canyons. It is represented by the Middle Temirlik lowlands with erosive steep-walled canyons, composed of porphyrites with ephemeralwormwood-forbs-vegetation on gray-brown gravelly soils. Here there is a very spectacular exposure of the ophiolites, which are the remains of the Cambrian paleocean, and are represented by serpentinized pyroxenites, gabbros, and diorites. Ophiolites compose a large and extended linear block of sub-latitudinal orientation, crossed by a deep gorge of the river. Temirlik canyons, in the walls of which the relationships between various rocks of the ophiolite association are clearly visible. To the south of the exposure of the ophiolites lies a stratum of layered phyllite schists and phyllitized schist sandstones, gravelites and conglomerates of the Shushanai Formation of the Upper Silurian (Walter, 1986). Conglomerates of this stratum contain pebbles of serpentinized ultrabasic rocks (which are known to have a high chromium content) with a large amount of a characteristic secondary mineral - bright green fuchsite - chromic mica.

On the laid geobotanical site (1x1) a description of the vegetation is made.

Semirechye wormwood (Artemisiaheptapotamica-wormwood Semirechenskaya) communities enriched with species of petrophytic forbs, ephedra thickets (Ephedraequisetina-horsetail, E.intermedia-ephedra, among the rocks and scree).

In Temirlik, there are 4 populations of Populus Salicaceae, 400 years old.

Project coverage - 50\% - quite plentiful

Vitality: medium not full bloom; does not grow in widespread clusters.

\section{RESULTS AND DISCUSSION}

Thus, in the Sharyn River Basin, the landscape structure represented by a full range of genetic types of localities - from watershed (eluvial) to floodplain (alluvial) are the key landscape areas that we identified - relic tracts Kurtogay, Moyyntokay, Temirlik and Sarytogay. These tracts are almost completely preserved from anthropogenic impact.

Currently, in accordance with functional zoning and according to the Management Program of the RGM "Sharyn State National Natural Park" for 2015-2019, 3 tourist routes have been developed (Management program, 2015):

1. The route "Nature Monument Sharyn Ash";

2. The route "Sharyn Canyon";

3. The route «Burial grounds and mounds».

All routes are seasonal from April to October. It offers visitors: On the route Sharyn Canyon: a yurt, a gazebo. The route is equipped with a viewing platform -2; descent; marked trail; buffer zone is indicated; parking - 1; panel signs -35. Roads: On the Sharyn Canyon, due to heavy rains, the dirt road is constantly eroded, constant leveling by a grader is required. The route "Sharyns ash forest" is equipped with a guest house for 6 people (with amenities); cottage for 6 people; gazebo with 50 seats. There is a dirt road to the guest house, for buses there is a special check-in. We studied tourism monitoring information (Management program, 2015). Based on this information, the authors compiled a passport of the recreational load on the protected natural territories of Sharyn (Table 1, 2) and dynamics tourists visiting these tourist sites along the routes (Table 3). From these data one can learn that very few foreign tourists visit such unique tourist sites. It also turned out that the most visited object in the protected areas are relict morphosculptures - Sharyn canyons. 
Table 1. "Passport" of the tourist route through the protected areas of Sharyn

\begin{tabular}{|c|c|c|c|}
\hline № & $\begin{array}{l}\text { Route } \\
\text { name }\end{array}$ & Route description & $\begin{array}{c}\text { Tourist } \\
\text { facilities }\end{array}$ \\
\hline 1 & 2 & 3 & 4 \\
\hline 1 & $\begin{array}{l}\text { Charyn } \\
\text { Canyon } \\
\text { "Valley of } \\
\text { Castles" }\end{array}$ & $\begin{array}{l}\text { Inspection of the Sharyn canyon "Valley of Castles" from the } \\
\text { observation deck located on top, then descent into the canyon. Passing } \\
\text { through the path network, the attention of tourists is drawn to the } \\
\text { beauty and grandeur of the pyramids, castles, towers, sculptures } \\
\text { created by the hand of nature. Is one of the well-visited objects with a } \\
\text { length of } 2 \mathrm{~km} \text {., Designed for } 1 \text { day, valid from April to October. This is } \\
\text { a geological - geomorphological tour, which is of particular value for } \\
\text { tourism and recreation. An opportunity to see the Kungei feather } \\
\text { grass, bristle-leaved onion, Kolpakovsky tulip. }\end{array}$ & $\begin{array}{l}\text { Muyntugai } \\
\text { Canyon }\end{array}$ \\
\hline 2 & $\begin{array}{c}\text { Monument } \\
\text { of nature } \\
\text { "Sharyn } \\
\text { Ash-tree } \\
\text { Grove" }\end{array}$ & $\begin{array}{l}\text { With a length of } 25 \mathrm{~km} \text {., Is designed for } 1 \text { day, valid from April to } \\
\text { October. This is a geobotanical tour in the Paleogene era. From the } \\
\text { observation deck you can see the beautiful panorama of the unique } \\
\text { plantings of ash. Then a descent into the floodplain of the Sharyn } \\
\text { River. Inspection of the clean plantings of Sogdian ash, special } \\
\text { attention is paid to its excellent natural renewal, familiarity with the } \\
\text { artificial plantations of ash on the second terrace, then the route runs } \\
\text { to the ash-tree, a long-lived ash, the diameter of which can cover } 7 \\
\text { people. Acquaintance with plant communities, with a variety of natural } \\
\text { landscapes, red book: barberry Iliysky, sea buckthorn, etc. }\end{array}$ & $\begin{array}{c}\text { Natural } \\
\text { boundary } \\
\text { Sarytogay }\end{array}$ \\
\hline 3 & $\begin{array}{l}\text { Burial } \\
\text { Grounds } \\
\text { and } \\
\text { mounds }\end{array}$ & $\begin{array}{l}\text { The route starts from the Shonzhi-Almaty highway, located in the } \\
\text { direction of the river Sharyn-Sarytogay. With a length of } 22 \mathrm{~km} \text {., Is } \\
\text { designed for } 1 \text { day, valid from May to October. This is a historical and } \\
\text { archaeological tour. The route starts from the Shonzhi-Almaty } \\
\text { highway, located in the direction of the river Sharyn-Sarytogay. The } \\
\text { first display facility of the Burial Grounds. The burial ground consists } \\
\text { of } 108 \text { barrows and ring stone fences. Mounds of mounds from earth } \\
\text { and stone, diameter } 3-16 \mathrm{~m} \text {, height o.1-1.2 m., } 17 \text { mounds and one } \\
\text { fence excavated. In burial mounds according to the rite of corpse, the } \\
\text { position of the head to the northwest. Funeral equipment, clay vessels, } \\
\text { a wooden bowl, iron knives, a bronze pendant, animal bones. BC. in } \\
\text { Kazakhstan there were relatively large associations with the } \\
\text { beginnings of state power. In the south-east, in Semirechye - this is } \\
\text { Uysuni. The most important source on the history of the Saka tribes, } \\
\text { their material, spiritual culture are archaeological sites - burial } \\
\text { grounds, mounds, cave paintings, treasures of Saka things, dwellings } \\
\text { of the Bronze Age. These were dugouts and half dugouts with walls 1-2 } \\
\text { m deep in the ground, made of stones in clay mortar. Here was located } \\
\text { the largest settlement in Semirechye with the presence of traces of the } \\
\text { irrigation system of the Early Iron Age. Scattered fragments of } \\
\text { cauldrons, jugs, bowls, as well as stone tools are visible on the surface. } \\
\text { Here, interesting locations of the oldest, now extinct representatives of } \\
\text { the fauna are preserved. Rich clumps of fossilized bones of mastodons, } \\
\text { elephants, rhinoceros, horses of Stenon, hyenas and many others were } \\
\text { found in the cliffs. Finds in the Miocene clays of the remains of a } \\
\text { hipparionic fauna - hipparion (a three-toed horse the size of a } \\
\text { donkey, a rhino that lived in shrubbery, a giraffe that lived in light } \\
\text { forests, an antelope and an ostrich. Then the route continues along the } \\
\text { left bank of the river Sharyn to the guest house, to get acquainted with } \\
\text { the exhibits of archaeological finds. After meeting with the cemeteries, } \\
\text { the group heads downstream of the Sharyn River to bypass No. } 2 \text {. }\end{array}$ & $\begin{array}{l}\text { Places where } \\
\text { they found } \\
\text { archaeological } \\
\text { and } \\
\text { paleontological } \\
\text { finds, burial } \\
\text { grounds, } \\
\text { mounds }\end{array}$ \\
\hline
\end{tabular}


Tourist and Recreational Potential of Landscapes of the

Specially Protected Natural Area of Sharyn of the Republic of Kazakhstan

Table 2. Passport of recreational load of protected areas Sharyn

\begin{tabular}{|c|c|c|c|c|c|c|}
\hline \multirow[b]{2}{*}{$\begin{array}{c}\text { Route } \\
\text { No. }\end{array}$} & \multirow[b]{2}{*}{ Route name } & \multirow[b]{2}{*}{ type of route } & \multirow{2}{*}{$\begin{array}{c}\text { The } \\
\text { length, } \mathrm{km} \text {. }\end{array}$} & \multirow[b]{2}{*}{ Seasonality } & \multicolumn{2}{|c|}{ Recreational load } \\
\hline & & & & & $\begin{array}{l}\text { Number } \\
\text { of days }\end{array}$ & $\begin{array}{l}\text { Number of } \\
\text { persons }\end{array}$ \\
\hline 1 & 2 & 3 & 4 & 5 & 6 & 7 \\
\hline 1 & "Sharyn Canyon" & $\begin{array}{l}\text { Car and pedestrian } \\
\text { route }\end{array}$ & $2 \mathrm{~km}$ & $\begin{array}{l}\text { April- } \\
\text { October }\end{array}$ & 1 & 30 \\
\hline 2 & $\begin{array}{l}\text { "Sharyn Ash- } \\
\text { tree Grove»" }\end{array}$ & $\begin{array}{l}\text { Car and pedestrian } \\
\text { route }\end{array}$ & $25 \mathrm{~km}$ & $\begin{array}{l}\text { April- } \\
\text { October }\end{array}$ & 1 & $30-50$ \\
\hline 3 & $\begin{array}{l}\text { «Burial grounds } \\
\text { and mounds» }\end{array}$ & $\begin{array}{c}\text { Car and pedestrian } \\
\text { route }\end{array}$ & $22 \mathrm{~km}$ & $\begin{array}{c}\text { May- } \\
\text { October }\end{array}$ & 1 & 140 \\
\hline
\end{tabular}

Table 3. Dynamics of tourists visiting the routes of protected areas Sharyn

\begin{tabular}{|c|c|c|c|}
\hline № & years & total number of visitors & including foreign tourists \\
\hline 1 & 2010 & 3700 & 300 \\
\hline 2 & 2012 & 3900 & 350 \\
\hline 3 & 2014 & 4200 & 370 \\
\hline 4 & 2016 & 4300 & 420 \\
\hline 5 & 2018 & 4400 & 800 \\
\hline
\end{tabular}

The chaotic unorganized descent into the canyon along the slopes is accompanied by a failure along the paths of the soil and vegetation cover, which results in water erosion of the slopes, which stimulates ravine formation, mudflows, and landslides. A progressive increase in tourists and sightseeing will further degrade the slopes of the canyon. In order to avoid the development of negative anthropogenic-stimulated processes, it is necessary to modernize the infrastructure of the territory.

For example, the construction of a cableway to descend into the canyon. This will not only prevent the erosion of the slopes, but also restore the vegetation cover, including the populations of some rare and endemic species. Thus, the infrastructure created in the connected areas will provide a reliable system of favorable conditions for research, development of both domestic and international tourism. Undoubtedly, in strict accordance with functional zoning, taking into account recreational loads. Based on the current situation, in order to relieve the anthropogenic load on the Sharyn Canyon, taking into account the previous scientific work of specialists, we propose to develop two more routes: "Small Canyon Kurtugay" and "Temirlik tract". When forming tourist routes, it is necessary to pay attention to the attractions located in the adjacent territories. Small Canyon is an ideal place for geological excursions.

The Small Canyon Kurtogay. The route will start from the border of the Sharyn Reserve, where an observation deck of $1.5 \mathrm{~km}$ will be installed. From the descent, on the starboard side of the canyon. Descent to a small canyon in the place "Bestamak". The path is 3300 meters along the bottom of the canyon. The path is defined as a buffer zone, 2 places for rest along the route. At the end of the path, on the banks of the Sharyn River under the Turang Forest, summer tables can be placed. In an open place, there can be placed a yurt with 10 seats, toilets, a kitchen, a barbecue for making barbecue.

Route Temirlik. Interesting geological attractions are located near the mountain estuary of the river Temirlik. The Temirlik route begins 3-4 km from the border of the Sharyn protected areas along the right bank of the Temirlik river. In the floodplain of the Temirlik River, Sharyn SNNP (State National Natural Park) administration plans to build a cordon, next to it is a guest house with 12 seats, a kitchen, a bathhouse, and a stable. Further, the route will be runs from the cordon to the mouth, i.e. where Temirlik flows into the Sharyn River. At the end of the path you can put a yurt, a gazebo, places for 
cooking, installation of barbecues, etc. In parallel with the footpath, you can plan an equestrian route. Currently, in the Sharyn Canyon - all geological, geomorphological, biological, paleontological natural monuments are protected.

\section{CONCLUSION}

Landscape refugium of protected areas Sharyn is one of the Kazakhstani and Central Asian pearls. Relict landscapes including piedmont plains, canyons and ash forests along the Sharyn River have great scientific, tourist and recreational potential. In combination with a variety of landscapes (canyons, small hills, deserts, wetlands, floodplain forests, etc.), a relic relief structure, the presence of historical and archeological monuments, this territory deserves special attention as an object with the potential for the development of international tourism. At the present stage, the natural conditions for the functioning of landscapes determine a high degree of their vulnerability; therefore, environmental requirements should become decisive in the design and organization of tourist and recreational activities here.

We have created a scientific database of tourist and recreational potential in the identified key landscape areas of protected areas Sharyn. This territory has the prospect of developing international tourism. Relict morphostructures and morphosculptures of the tract Kurtogay, Moyyntokay and Temirlik, refugia Sarytogay - Ashen grove, are sources of information on the interaction of endogenous and exogenous processes of landscape formation in this territory. And they have not only scientific and aesthetic significance, they are also natural monuments, invaluable tourist and recreational resources. Sharyn with its unique landscapes is a good choice for those interested in geology, nature and history. Almaty region borders on the People's Republic of China. The development of international tourism would be one of the sources of income for the local population of the Uigur and Kegen regions.

Thus, the authors suggest that the location and natural features of Sharyn can bring the best level of tourism experience in this part of Kazakhstan.

\section{REFERENCES}

Akbar, I., Yang, Zh., Mazbayev O., Seken A. \& Udahogora M. (2020). Local residents' participation in tourism at a world heritage site and limitations: a case of Aksu-Jabagly natural world heritage site, Kazakhstan. GeoJournal of Tourism and Geosites, 28 (1), 35-51.

Aliyeva S., Chen Xi., Yang D., Kanat Samarkhanov K., Mazbayev O., Sekenuly A., Issanova G. \& Kozhokulov S. (2019). The Socioeconomic Impact of Tourism in East Kazakhstan Region: Assessment Approach. Sustainability, 11 (17), 1-14.

Aubekerov, B., Sala R., Nigmatova S.A. \& Zhakupova Sh.A. (2003). Changes in atmospheric circulation, paleoclimate and paleogeography in the Tien Shan-Balkhash system. Pages news, 11, 24-26.

Beruchashvili, N.L. \& Zhuchkova, N.L. (1977). Methods of complex physical and geographical research. Moscow: Publishing house of Moscow University.

Betemesov T.A. \& Toktasynov Zh.N. (2013). The current state and protection of Sogdian ash. Proceedings of the Charyn State National Natural Park, 1, 15-25.

Burgi, M., Ali, P., Chowdhury,A., Heinimann, A., Hett, C., Kienast, F., Mondal, M.K., Upreti, B.R. \& Verburg, P.H. (2017). Integrated landscape approach: Closing the gap between theory and application. Sustainability (Switzerland), 9 (8), pp. 1371.

Chibilev, A.A. (2011). Key landscape areas as the fundamental basis of the natural heritage of Russia. Geographical basis for the formation of ecological networks in Russia and Eastern Europe. Materials of electronic conf. Partnership of scientific publications of KMK, 1, 303-308.

Dunets, A.N. (2011). Tourist and recreational space of a mountainous cross-border region: organization theory and development. ABSTRACT dissertation for the degree of Doctor of Geographical Sciences. St. Petersburg: Publishing House Saint Petersburg State University. 
Gorbunov, A.P., \& Gorbunova, I.A. (2013). Charyn Canyons. Journal Academic Publishing Center "Science" RAS. Nature, 9, 77-82.

Janaleyeva, K.M. (1993). The landscape structure of the Balkhash-Ili mega-geosystem. Alma-Ata: KazNU.

Janaleyeva, K.M. (2010). Physical geography of the Republic of Kazakhstan. Astana: ENU named after L.N. Gumilyov, "Arkas”.

Kabiyev Y.S, , Berdenov Z.G., Kulchihan M.D., Atasoy E., \& Wendt J.A. (2018). Landscape ecological analysis of the modern delta of the Ural (Zhayik) river. GeoJournal of Tourism and Geosites, 11 (3), pp. 644-655.

Kerimbay, N.N. (2015). Rational use of landscapes of geosystems of the Sharyn River basin. Saarbrucken, Germany: LAP Lambert Academic Publishing Heinrich-Böcking-Str.

Kerimbay, N.N. (1998). Intramountain valley landscapes of the Sharyn river basin. Search, 1, 58-61.

Kolisnichenko, Yu.S., Sartbaev, Zh.T., \& Nurgaliev A.E. (2013). To the study of the forest pathological state of the Sharyn forest Asheneva dacha. Materials of the International scientific-practical conference "Development of the" green economy "and the conservation of biological diversity" Schuchinsk: 189-194.

Krauklis, A.A. (1979). Problems of experimental landscape science. Novosibirsk: Siberian Branch.

Makunina, G.S.(1987). Methodology of field physical and geographical research. The structure and dynamics of the landscape. Moscow: Publishing House of Moscow University.

Mazhitova, G.Z., Pashkov, S.V., \& Wendt J.A. (2018). Assessment of landscape ecological - recreational capacity of north Kazakhstan region. GeoJournal of Tourism and Geosites, 11 (3), 731-737.

Nazarova, T.V., Fomin, I.A., Dmitriev, P.S., Wendt, J.A., \& Janaleyeva, K.M. (2019). Landscape and limnological research of lake system of the plain areas of the northeastern borderlands of the Republic of Kazakhstan and assessment of their recreational capacity. GeoJournal of Tourism and Geosites, 25 (2), 485-495

Ogar, N.P., Geldyev, B.V., \& Mirkhashimov I.Kh. (1997). On the organization of the Charyn National Nature Park to preserve the biodiversity of ecosystems in the Iliysky intermountain basin. Biological and landscape diversity of the Republic of Kazakhstan. Almaty, 98-102.

Solntsev, V.N. (1981). Systemic organization of landscapes: problems of methodology and theory. Moscow: Thought.

Snytko, V.A., \& Semenov. Yu.M. (2008). The study of geosystem structure, development and functioning in Siberia. Methodology of landscape research. Commission of Cultural Landscape of Polish Geographical Society, Sosnowiec, 9, 141-150.

Tandaric, N. (2015). Towards a general theory of landscape systems: the integration of the geoecological and bioecological approaches. Miscellanea geographica - regional studies on development, 19(1), 29-34

Veselova, L.K ., \& Shmarova, I.N. (2016). Geomorphological systems of the Sharyn State National Natural Park. Bulletin of the Kazakh National University. Physical, economic and social geography, 42(1), 17-21.

Walter, S. (1986). The world of stone. V.1. Rocks and minerals., Moscow: Mir.

Wendt, J.A., \& Bógdał-Brzezińska, Ag. (2018). Problematyka, metody i problemy badań w geografii turystycznej Turystyka: nowe trendy. Publisher: Polska Izba Turystyki Oddziat w Gdańsku, 7, 7-42

Wintergoller, B. A. (1984. Relics around us. Alma-Ata:Science.

Zhandaev, M.Zh. (1972). Geomorphology of Zailiysky Alatau. Alma-Ata: Science.

*** Chronicle of nature, $\S 1$, (2018). Changes in the surface topography on the territory of the Sharyn SNNP for 2006-2018. The state and dynamics of changes in the elements of the abiotic environment. Scientific Department of SHSNNP. Shoongy.

*** Chronicle of nature, $\delta 2,(2018)$. State and dynamics of change of elements biological complex on the territory of the Sharyn SNNP for 2006-2018. Rare and endangered plant species, endemic and relics. Scientific Department of SHSNNP. s. Shoongy.

*** Management program, (2015). RGM "Sharyn SNNP " for 2015-2019. Department of SHSNNP. Shoongy.

*** The management plan of the RGU "Sharyn State National Natural Park" for 2015-2019. (2015). Scientific Department of SHSNNP. Shoongy.

Submitted:

07.10.2019
Revised:

23.01.2020
Accepted and published online 27.01.2020 